\title{
The Profile of Psoriasis Vulgaris Patients: A Descriptive Study
}

\author{
Cita Rosita Sigit Prakoeswa ${ }^{1}$, Afif Nurul Hidayati ${ }^{1}$, Made Putri Hendaria ${ }^{1}$ (D), M. \\ Yulianto Listiawan', Budi Utomo ${ }^{2}$, Damayanti', Irmadita Citrashanty ${ }^{1}$, Sylvia \\ Anggraeni ${ }^{1}$, Menul Ayu Umborowati ${ }^{1}$, Evy Ervianti ${ }^{1}$ \\ ${ }^{1}$ Departement of Dermatology and Venereology, Faculty of Medicine Universitas Airlangga/Dr. \\ Soetomo General Academic Hospital, Universitas Airlangga Teaching Hospital, Surabaya, Indonesia \\ ${ }^{2}$ Department of Public Health Sciences, Faculty of Medicine, Universitas Airlangga, Surabaya, \\ Indonesia
}

\begin{abstract}
Background: Psoriasis is a skin disease that occurs due to proliferation and differentiation disturbances of the epidermis. This chronic condition often reduces the human quality of life. There have been studies investigating psoriatic patient profiles and treatments, but few are conducted in Surabaya. Hence, those studies cannot fully represent the population demographic in Surabaya. Purpose: To investigate the prevalence of psoriasis vulgaris and the sociodemographic profile of the patients in Dr Soetomo General Academic Hospital. Methods: This was a Retrospective study psoriasis vulgaris patients in January 2016-December 2018. The data were collected by retrieving Electronic Medical Records (EMR) as secondary data. Result: The psoriasis vulgaris prevalence of outpatients was $0.46 \%$ and $4.59 \%$ in inpatients. Most study subjects were adults aged 18 and above $(98.1 \%)$, most of the patients were obese $(46.3 \%)$, the most common provoking factor was focal tooth infection (33.8\%) and stress (28.8\%), and none reported family history of psoriasis. Conclusion: Some results are similar to other studies conducted in Surabaya, which were the obesity and Type 2 Diabetes Mellitus (DM) being strong a factor to psoriasis development. However, the result on psoriasis family history was not in line with other studies.
\end{abstract}

Keywords: psoriasis vulgaris, patient profile, severity, treatment, human and disease.

Correspondence: Afif Nurul Hidayati, Department of Dermatology and Venereology Faculty of Medicine, Universitas Airlangga/Dr. Soetomo General Academic Hospital/Universitas Airlangga, Surabaya, J1. Mayjen Prof. Dr. Moestopo No. 6-8 Surabaya 60131, Indonesia. Phone: (031) 5501609, e-mail: afif_nurulhidayati@fk.unair.ac.id.

Article info | Submited: 2-6-2021, Accepted: 20-7-2021, Published: 30-11-2021

\section{BACKGROUND}

Psoriasis is an inflammatory skin disease with chronic immunologic mediation, and it is often found with characteristics such as epidermal hyperplasia, increased arthritis risk, cardiovascular morbidity, and psychosocial problems. ${ }^{1}$ It is marked by erythematous plaque covered with thick white squamous layers that occur due to proliferation and differentiation disturbances of the epidermis. ${ }^{1,2}$ It is a multifactorial disease in which pathogenesis is not fully understood but is thought to relate to genetic predisposition, autoimmune disease, and other environmental factors. $^{1,3}$ It is also thought to arise from abnormal interactions of the innate immune system in which the cells involved are keratinocytes, dendritic cells, T lymphocytes, neutrophils, and mast cells. ${ }^{1,4}$

The estimated prevalence of adult psoriasis ranges from $0.51 \%$ to $11.43 \%$, increasing globally. 5,6 In Indonesia, a retrospective study by Gayatri shows an equal predilection between males and females. The disease could occur in various stages of life but mainly occurred in 15 to 40 years old, rarely found in ages less than ten years old. ${ }^{7}$ The many types of psoriasis, psoriasis vulgaris is the most common and is observed in $90 \%$ of patients. ${ }^{1,8}$ Surabaya is the second-largest city in Indonesia, second to the capital city of Jakarta. As of January 2019, it is home to 3 million people. Despite being populous, there are still established epidemiological data regarding psoriasis vulgaris that represent the demographic of people in Surabaya. ${ }^{9}$

A thorough physical examination is required for diagnosis because laboratory examination does not usually present specific outcomes. Additionally, histopathologic studies are needed in diagnosing complex cases. ${ }^{1,10}$ In choosing a therapeutic regiment, it is important to consider the scale and severity of the lesion. ${ }^{1,11,12}$ Severity of psoriasis can be scored with Psoriasis Area and Severity Index (PASI), which combines severity and area of lesions in a single index score. ${ }^{13}$ Successful treatment means $75 \%$ lower of the initial PASI score, known as PASI $75 .^{10} \mathrm{~A}$ number of 
topical that are available such as topical corticosteroid, vitamin D analogue, tazarotene, and calcineurin inhibitor. ${ }^{1,14}$ Furthermore, systemic agents include cyclosporine A, methotrexate, acitretin fumarate, hydroxyurea, acid esters, 6-thioguanine, sulfasalazine, mycophenolate mofetil, apremilast, and tofacitinib. ${ }^{1}$ Another therapeutic mechanism that can be combined with the former includes phototherapy, which thins $\mathrm{T}$ cells selectively, especially those on the epidermis, prompting apoptosis and shifting of response from Th1 to Th2. 1,8

This retrospective study is aimed to evaluate the profiles of psoriasis vulgaris patients of Dr Soetomo General Academic Hospital in Surabaya, ranging from their general profiling, disease severity, and prescribed treatment.

\section{RESULT}

Table 1. Characteristics of psoriasis vulgaris patients

\begin{tabular}{|c|c|c|c|c|}
\hline Variables & $\begin{array}{l}2016 \\
\mathrm{n}(\%)\end{array}$ & $\begin{array}{l}2017 \\
\mathrm{n}(\%)\end{array}$ & $\begin{array}{l}2018 \\
\mathrm{n}(\%)\end{array}$ & $\begin{array}{l}\text { Total } \\
\mathrm{n}(\%)\end{array}$ \\
\hline \multicolumn{5}{|l|}{ Outpatient } \\
\hline \multicolumn{5}{|l|}{ Sex } \\
\hline Male & $1(33.3)$ & $4(33.3)$ & $22(55.0)$ & $27(50.0)$ \\
\hline Female & $2(66.7)$ & $8(66.7)$ & $17(45.0)$ & $27(50.0)$ \\
\hline \multicolumn{5}{|l|}{ Age } \\
\hline$<18$ years & $0(0)$ & $1(7.7)$ & $0(0)$ & $1(1.9)$ \\
\hline$\geq 18$ years & $3(100)$ & $12(92.3)$ & $39(100)$ & $54(98.1)$ \\
\hline \multicolumn{5}{|l|}{ Job } \\
\hline Housewife & $1(100)$ & $5(41.7)$ & $10(25.6)$ & $16(29.6)$ \\
\hline Civil servants & $1(100)$ & $0(0)$ & $9(23.1)$ & $10(18.5)$ \\
\hline Private employees & $1(100)$ & $6(50)$ & $16(41)$ & $23(42.6)$ \\
\hline Student & $0(0)$ & $1(8.3)$ & $0(0)$ & $1(1.9)$ \\
\hline Entrepreneur & $0(0)$ & $0(0)$ & $4(10, .3)$ & $4(7.4)$ \\
\hline \multicolumn{5}{|l|}{ BMI } \\
\hline$<18.5 \mathrm{~kg} / \mathrm{m}^{2}$ & $0(0)$ & $3(25)$ & $0(0)$ & $3(5.6)$ \\
\hline $18.5-22.9 \mathrm{~kg} / \mathrm{m}^{2}$ & $0(0)$ & $5(41.7)$ & $23(59)$ & $28(51.9)$ \\
\hline$\geq 23.0 \mathrm{~kg} / \mathrm{m}^{2}$ & $3(100)$ & $4(33.3)$ & $16(41)$ & $23(42.6)$ \\
\hline \multicolumn{5}{|l|}{ Predilection areas } \\
\hline Scalp & $0(0)$ & $2(16.7)$ & $5(12.9)$ & $7(13.0)$ \\
\hline Upper extremities & $3(100)$ & $11(91.7)$ & $36(92.3)$ & $50(92.6)$ \\
\hline Lower extremities & $3(100)$ & $12(100)$ & 35 (89.7) & $50(92.6)$ \\
\hline Back and chest & $3(100)$ & $12(100)$ & $34(87.1)$ & $49(90.7)$ \\
\hline \multicolumn{5}{|l|}{ Provoking factors } \\
\hline Tooth focal infection & $2(66.7)$ & $2(16.7)$ & $16(41)$ & $20(37)$ \\
\hline ENT focal infection & $0(0)$ & $5(41.6)$ & $4(10.3)$ & $9(16.7)$ \\
\hline Stress & $1(33.3)$ & $4(33.3)$ & $13(33.3)$ & $18(33.3)$ \\
\hline Low compliance & $0(0)$ & $1(8,3)$ & $4(10.3)$ & $5(9.3)$ \\
\hline Unknown & $0(0)$ & $0(0)$ & $2(5.1)$ & $2(3.7)$ \\
\hline \multicolumn{5}{|l|}{ Family history } \\
\hline Yes & $0(0)$ & $0(0)$ & $0(0)$ & $0(0)$ \\
\hline No & $3(100)$ & $12(100)$ & $39(100)$ & $54(100)$ \\
\hline Biopsy result & & & & \\
\hline
\end{tabular}

\section{METHODS}

This research was a retrospective descriptive study of psoriasis vulgaris involving inpatients and outpatients of Dr Soetomo General Academic Hospital, Departement of Dermatology and Venereology. The secondary data were obtained through the electric medical record (EMR) of psoriasis vulgaris patients admitted from January 2016 to December 2018.

The inclusion criterion was medical records containing PASI scores before and after treatment. Data collected include general sex, age, body mass index (BMI), predilected areas, provoking factors, family history, and biopsy results. Ethical clearance was obtained from the Ethical Committee of Dr Soetomo General Academic Hospital Surabaya with reference number: 1979/KEPK/IV/2020. 


\begin{tabular}{|c|c|c|c|c|}
\hline Fitting psoriasis & $0(0)$ & $7(58.3)$ & $31(79.4)$ & $38(70.4)$ \\
\hline Not fitting & $2(66.7)$ & $5(41.7)$ & $6(15.6)$ & $13(24)$ \\
\hline No result & $1(33.3)$ & $0(0)$ & $2(5)$ & $3(5.6)$ \\
\hline \multicolumn{5}{|l|}{ Inpatient } \\
\hline \multicolumn{5}{|l|}{ Sex } \\
\hline Male & $4(80)$ & $9(56.3)$ & $3(60)$ & $16(61.5)$ \\
\hline Female & $1(20)$ & $7(43.8)$ & $2(40)$ & $10(38.5)$ \\
\hline \multicolumn{5}{|l|}{ Age } \\
\hline$<18$ years & $0(0)$ & $2(12.5)$ & $1(20)$ & $3(11.5)$ \\
\hline$\geq 18$ years & $5(100)$ & $14(87.5)$ & $4(80)$ & $23(88.5)$ \\
\hline \multicolumn{5}{|l|}{ Job } \\
\hline Housewife & $1(20)$ & $5(31.3)$ & $1(20)$ & $7(26.9)$ \\
\hline Civil servants & $1(20)$ & $1(6.3)$ & $0(0)$ & $2(7.7)$ \\
\hline Private employees & $2(40)$ & $6(37.5)$ & $2(40)$ & $10(48.5)$ \\
\hline Student & $0(0)$ & $1(6.3)$ & $0(0)$ & $2(7.7)$ \\
\hline Entrepreneur & $1(20)$ & $2(12.5)$ & $0(0)$ & $3(11.5)$ \\
\hline Others & $0(0)$ & $0(0)$ & $1(20)$ & $1(3.8)$ \\
\hline Unemployed & $0(0)$ & $1(6.3)$ & $0(0)$ & $1(3.8)$ \\
\hline \multicolumn{5}{|l|}{ BMI } \\
\hline$<18.5 \mathrm{~kg} / \mathrm{m}^{2}$ & $0(0)$ & $1(6.3)$ & $1(20)$ & $2(7.7)$ \\
\hline $18.5-22.9 \mathrm{~kg} / \mathrm{m}^{2}$ & $1(20)$ & $5(31.3)$ & $3(60)$ & $9(34.6)$ \\
\hline$\geq 23.0 \mathrm{~kg} / \mathrm{m}^{2}$ & $4(80)$ & $10(62.3)$ & $1(20)$ & $15(57.7)$ \\
\hline \multicolumn{5}{|l|}{ Predilection areas } \\
\hline Scalp & $3(60)$ & $5(31.3)$ & $3(60)$ & $11(42.3)$ \\
\hline Upper extremities & $4(80)$ & $16(100)$ & $5(100)$ & $25(96.2)$ \\
\hline Lower extremities & $5(100)$ & $16(100)$ & $5(100)$ & $26(100)$ \\
\hline Back and chest & $5(100)$ & $16(100)$ & $5(100)$ & $26(100)$ \\
\hline Behing & $1(20)$ & $1(6.3)$ & $0(0)$ & $2(7.7)$ \\
\hline \multicolumn{5}{|l|}{ Provoking factors } \\
\hline Tooth focal infection & $2(40)$ & $4(25)$ & $1(20)$ & $7(26.7)$ \\
\hline ENT focal infection & $1(20)$ & $3(18.8)$ & $0(0)$ & $4(15.4)$ \\
\hline Stress & $1(20)$ & $3(18.8)$ & $1(20)$ & $5(19.2)$ \\
\hline Low compliance & $0(0)$ & $3(18.8)$ & $1(20)$ & $4(15.4)$ \\
\hline Unknown & $2(40)$ & $3(18.8)$ & $2(40)$ & $7(26.9)$ \\
\hline \multicolumn{5}{|l|}{ Family history } \\
\hline Yes & $0(0)$ & $0(0)$ & $0(0)$ & $0(0)$ \\
\hline No & $5(100)$ & $16(100)$ & $5(100)$ & $26(100)$ \\
\hline \multicolumn{5}{|l|}{ Biopsy result } \\
\hline Fitting psoriasis & $4(80)$ & $13(81.3)$ & $3(60)$ & $20(76.9)$ \\
\hline Not fitting & $1(20)$ & $3(18.8)$ & $2(40)$ & $6(23.1)$ \\
\hline No result & $0(0)$ & $0(0)$ & $0(0)$ & $0(0)$ \\
\hline
\end{tabular}

BMI: Body Mass Index

ENT : Ear, Nose, Throat

The table above shows that the distribution of sex of outpatient was balanced. Most of them were older than 18 years old (98.1\%), and most of them worked as private employees (42.6\%) and housewives $(29.6 \%)$. More than half of the outpatients have a normal BMI. The majority of the patients have predilections in the upper extremities, lower extremities, and back and chest, with $92.6 \%, 92.6 \%$, and $90.7 \%$, respectively. The most often provoking factors are tooth focal infection and stress. All outpatients have no family history of psoriasis.

For inpatients, $88.5 \%$ of them were 18 years old and above. Most inpatients were males (61.5\%), and most of their occupation was private employees, followed by housewives. More than half have excessive weight. The lesions mainly occurred around the lower extremities, back, and chest $(100 \%$ each), followed by upper extremities $(96,2 \%)$. The most provoking factors were tooth focal infection and 
stress. None have a family history of psoriasis. A small portion of psoriatic outpatient (24\%) and inpatient $(23.1 \%)$ have biopsy result that does not fit with psoriasis pictures. The diagnosis is based upon clinical exam, while biopsy functions assist the diagnosis in atypical or doubtful cases. Three biopsy results of outpatients are not found on the record, which may be suspected to them refusing biopsy or having biopsied somewhere else.

Type $2 \mathrm{DM}$ is the most common comorbidity inpatients and outpatients, presenting $30.8 \%$ and $29.6 \%$, respectively, followed by dyslipidemia

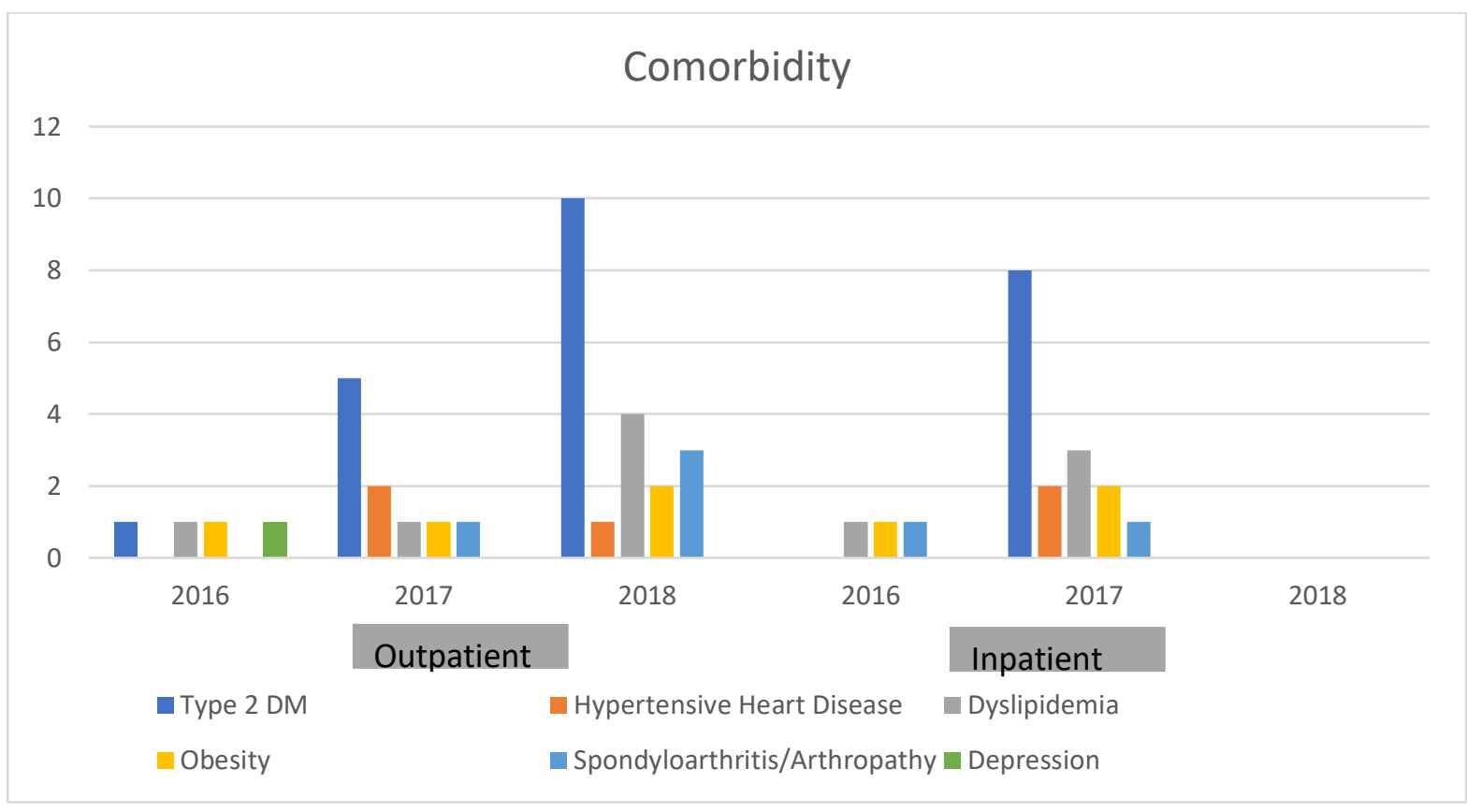

DM: Diabetes Mellitus

Figure 1. Comorbidity of in- and outpatients of psoriasis vulgaris in Dermatology and Venereology Department of Dr. Soetomo General Academic Hospital Period January 2016 - December 2018.

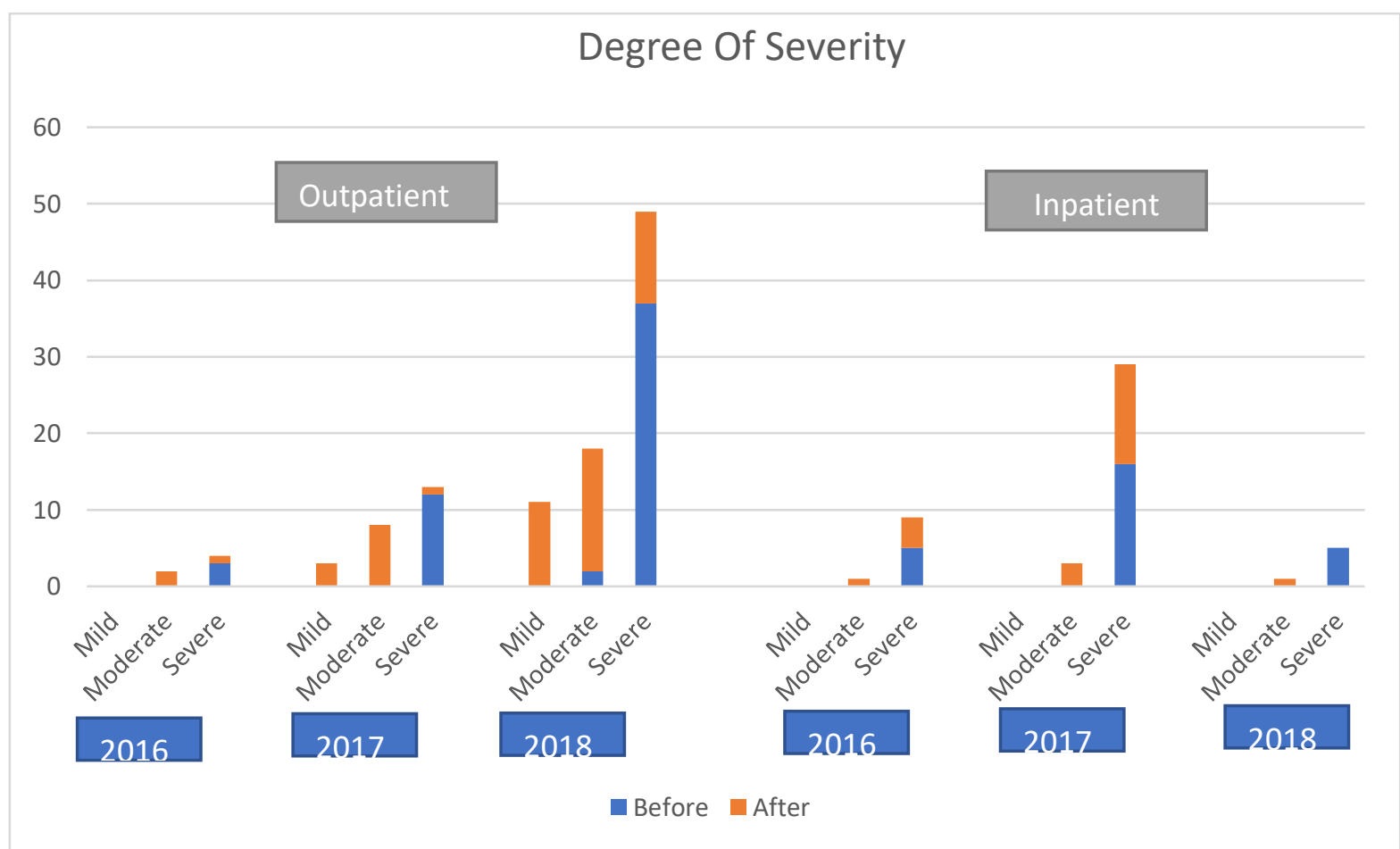

Figure 2. In- and outpatient psoriasis vulgaris degree of severity before and after treatment in Dermatology and Venereology Department of Dr. Soetomo General Academic Hospital Period January 2016 December 2018. 
Almost all (96.3\%) outpatient subjects have severe psoriasis, and no patient has mild psoriasis at the beginning of the regimen. By the end, most outpatient issues have moderate psoriasis (48.1\%). On the other hand, $100 \%$ of inpatient subjects had severe psoriasis at the beginning of the treatment which $19.2 \%$ revert to moderate psoriasis, leaving $80.8 \%$ of severe psoriasis inpatients at the end. Thirty-five outpatients out of 54 achieved PASI 75, success treatment, by the end of the treatment, while only one inpatient out of twenty-six could accomplish the same.

For outpatients subjects, $92.6 \%$ received a combination of topical and systemic therapy because all outpatients have moderate and severe psoriasis and no mild psoriasis. Four severe psoriasis patients have topical, systemic, and phototherapy regimens. Since all inpatients started with severe psoriasis (PASI $>10$ ), all of them were treated with a combination of topical and systemic therapy.

Table 2. Success rate of PASI 75 on psoriasis vulgaris treatment

\begin{tabular}{|c|c|c|c|c|}
\hline PASI 75 & $\begin{array}{l}2016 \\
\mathrm{n}(\%)\end{array}$ & $\begin{array}{l}2017 \\
\mathrm{n}(\%)\end{array}$ & $\begin{array}{l}2018 \\
\mathrm{n}(\%)\end{array}$ & $\begin{array}{l}\text { Total } \\
\mathrm{n}(\%)\end{array}$ \\
\hline \multicolumn{5}{|l|}{ Outpatient } \\
\hline Achieved & $2(66.7)$ & $11(91,7)$ & $22(56.4)$ & $35(64.8)$ \\
\hline Unachieved & $1(33.3)$ & $1(98.3)$ & $17(43.6)$ & $19(35.2)$ \\
\hline \multicolumn{5}{|l|}{ Inpatient } \\
\hline Achieved & $0(0)$ & $0(0)$ & $1(20)$ & $1(3.8)$ \\
\hline Unachieved & $5(100)$ & $16(100)$ & $4(80)$ & $25(96.2)$ \\
\hline
\end{tabular}

PASI : Psoriasis Area and Severity Index

Table 3. Type of therapy for psoriasis vulgaris

\begin{tabular}{|c|c|c|c|c|}
\hline Type & $\begin{array}{l}2016 \\
\mathrm{n}(\%)\end{array}$ & $\begin{array}{l}2017 \\
\mathrm{n}(\%)\end{array}$ & $\begin{array}{l}2018 \\
\mathrm{n}(\%)\end{array}$ & $\begin{array}{l}\text { Total } \\
\mathrm{n}(\%)\end{array}$ \\
\hline \multicolumn{5}{|l|}{ Outpatient } \\
\hline Topical and systemic & $3(100)$ & $12(100)$ & $35(89.7)$ & $50(92.6)$ \\
\hline Topical, systemic, and phototherapy & $0(0)$ & $0(0)$ & $4(10.3)$ & $4(7.4)$ \\
\hline \multicolumn{5}{|l|}{ Inpatient } \\
\hline Topical and systemic & $5(100)$ & $16(100)$ & $5(100)$ & $26(100)$ \\
\hline
\end{tabular}

Table 4. Type of topical therapy of psoriasis vulgaris

\begin{tabular}{|c|c|c|c|c|}
\hline Type & $\begin{array}{l}2016 \\
\mathrm{n}(\%)\end{array}$ & $\begin{array}{l}2017 \\
\mathrm{n}(\%)\end{array}$ & $\begin{array}{l}2018 \\
\mathrm{n}(\%)\end{array}$ & $\begin{array}{l}\text { Total } \\
\mathrm{n}(\%)\end{array}$ \\
\hline \multicolumn{5}{|l|}{ Outpatient } \\
\hline Vaseline album & $0(0)$ & $6(50)$ & $14(61.5)$ & $30(55.6)$ \\
\hline Urea $10 \%$ cream & $1(33.3)$ & $9(75)$ & $19(48.7)$ & $29(53.7)$ \\
\hline Hydrocortisone $2.5 \%$ cream & $0(0)$ & $1(8.3)$ & $5(12.8)$ & $6(11.1)$ \\
\hline Momethasone furoate $0.1 \%$ cream & $1(33.3)$ & $9(75)$ & $28(71.8)$ & $38(70.4)$ \\
\hline Desoximethasone $0.25 \%$ cream & $3(100)$ & $12(100)$ & $36(92.3)$ & $51(94.4)$ \\
\hline Clobetasol proprionate $0.05 \%$ cream & $0(0)$ & $1(8.3)$ & $1(2.6)$ & $2(3.7)$ \\
\hline Desonide Lotion & $0(0)$ & $2(16.7)$ & $11(28.2)$ & $13(24.1)$ \\
\hline \multicolumn{5}{|l|}{ Inpatient } \\
\hline Oleum coccos & $0(0)$ & $0(0)$ & $2(40)$ & $2(7.7)$ \\
\hline Vaseline album & $2(40)$ & $14(87.5)$ & $2(40)$ & $18(69.2)$ \\
\hline Urea $10 \%$ cream & $1(20)$ & $1(6.3)$ & $0(0)$ & $2(7.7)$ \\
\hline Hydrocortisone $2.5 \%$ cream & $0(0)$ & $0(0)$ & $1(20)$ & $1(3.8)$ \\
\hline Momethasone furoate $0.1 \%$ cream & $4(80)$ & $8(50)$ & $1(20)$ & $13(50)$ \\
\hline Desoximethasone $0.25 \%$ cream & $5(100)$ & $14(87.5)$ & $4(80)$ & $23(88.5)$ \\
\hline Clobetasol proprionate $0.05 \%$ cream & $0(0)$ & $1(6.3)$ & $0(0)$ & $1(3.8)$ \\
\hline Desonide Lotion & $2(40)$ & $3(18.8)$ & $0(0)$ & $5(19.2)$ \\
\hline
\end{tabular}


Table 5. Type of systemic therapy of psoriasis vulgaris

\begin{tabular}{|c|c|c|c|c|}
\hline Type & $\begin{array}{c}2016 \\
\mathrm{n}(\%)\end{array}$ & $\begin{array}{l}2017 \\
n(\%)\end{array}$ & $\begin{array}{l}2018 \\
\mathrm{n}(\%)\end{array}$ & $\begin{array}{l}\text { Total } \\
\mathrm{n}(\%)\end{array}$ \\
\hline \multicolumn{5}{|l|}{ Outpatient } \\
\hline Methrotrexate & $2(66.7)$ & $8(66.7)$ & $29(74.4)$ & $39(72.2)$ \\
\hline Cyclosporine & $0(0)$ & $1(8.3)$ & $0(0)$ & $1(1.9)$ \\
\hline Folic acid & $3(100)$ & 11(91.7) & $32(82.1)$ & $46(85.2)$ \\
\hline CTM & $0(0)$ & $0(0)$ & $2(5.1)$ & $2(3.7)$ \\
\hline Loratadin & $0(0)$ & $0(0)$ & $14(35.9)$ & $14(25.9)$ \\
\hline Cetirizine & $2(66.7)$ & $12(100)$ & $35(89.7)$ & $49(90.7)$ \\
\hline \multicolumn{5}{|l|}{ Inpatient } \\
\hline Methrotrexate & $5(100)$ & $10(62.5)$ & $5(100)$ & $20(76.9)$ \\
\hline Cyclosporine & $0(0)$ & $4(25)$ & $0(0)$ & $4(15.4)$ \\
\hline Folic acid & $4(80)$ & $9(56.3)$ & $2(40)$ & $15(57.7)$ \\
\hline CTM & $3(60)$ & $2(12.5)$ & $1(20)$ & $6(23.1)$ \\
\hline Cetirizine & $4(80)$ & $13(81.3)$ & $4(80)$ & $21(80.8)$ \\
\hline
\end{tabular}

CTM : Chlorphenamine maleate

Table 6. Methotrexate doses on psoriasis vulgaris treatment

\begin{tabular}{|c|c|c|c|c|}
\hline MTX (/week) & $\begin{array}{l}2016 \\
\mathrm{n}(\%)\end{array}$ & $\begin{array}{l}2017 \\
\mathrm{n}(\%)\end{array}$ & $\begin{array}{l}2018 \\
\mathrm{n}(\%)\end{array}$ & $\begin{array}{l}\text { Total } \\
\mathrm{n}(\%)\end{array}$ \\
\hline \multicolumn{5}{|l|}{ Outpatient } \\
\hline $2.5 \mathrm{mg}$ & $0(0)$ & $0(0)$ & $3(10.3)$ & $3(7.7)$ \\
\hline $5 \mathrm{mg}$ & $1(50)$ & $0(0)$ & $1(3.4)$ & $2(5.1)$ \\
\hline $7.5 \mathrm{mg}$ & $0(0)$ & $0(0)$ & $1(3.3)$ & $1(2.6)$ \\
\hline $10 \mathrm{mg}$ & $0(0)$ & $0(0)$ & $3(10.3)$ & $3(2.6)$ \\
\hline $12.5 \mathrm{mg}$ & $0(0)$ & $2(25)$ & $3(10.3)$ & $5(12.8)$ \\
\hline $15 \mathrm{mg}$ & $1(50)$ & $6(75)$ & $7(58.6)$ & $24(61.5)$ \\
\hline $25 \mathrm{mg}$ & $0(0)$ & $0(0)$ & $1(3.4)$ & $1(2.6)$ \\
\hline \multicolumn{5}{|l|}{ Inpatient } \\
\hline $2.5 \mathrm{mg}$ & $0(0)$ & $0(0)$ & $1(20)$ & $1(5)$ \\
\hline $7.5 \mathrm{mg}$ & $0(0)$ & $0(0)$ & $1(20)$ & $1(5)$ \\
\hline $10 \mathrm{mg}$ & $0(0)$ & $1(10)$ & $0(0)$ & $1(5)$ \\
\hline $15 \mathrm{mg}$ & $5(100)$ & $8(80)$ & $3(60)$ & $16(80)$ \\
\hline $17.5 \mathrm{mg}$ & $0(0)$ & $1(10)$ & $0(0)$ & $1(5)$ \\
\hline
\end{tabular}

MTX : Methrotrexate

\section{DISCUSSION}

The average psoriasis vulgaris prevalence in the outpatient Department of Dermatology and Venerology of Dr Soetomo General Academic Hospital, Surabaya, between January 2016-December 2018 was $0.19 \%$, with an increasing trend of prevalence from 2016 to 2018. Additionally, the prevalence rate of psoriasis vulgaris in the inpatient department was $3.98 \%$, corresponding to the global prevalence of $0.09 \%-11.4 \%{ }^{15}$ The number has not been compared with the prevalence in Indonesia due to a lack of data. In 2007-2008, studies conducted in Jakarta, Indonesia, reported that the psoriasis prevalence was $1.73 \%$, with most $(82.98 \%)$ were psoriasis vulgaris. ${ }^{16}$ The distribution of sex in outpatient subjects was balanced, while in inpatient subjects, it was dominated by males. Globally, studies found that the sex distribution of psoriasis patients is similar. ${ }^{15}$

Most of the outpatients were 18 years old and above. It also corresponds to numerous findings that psoriasis is more prevalent in the adult population, which increases with age. The average onset of psoriasis is 33 years old. Three-fourths of them occur before the age of $46 .{ }^{15}$ The predilection location in this study shows to be within the upper and lower extremities and back and chest. These predilection locations are typical of the psoriasis type. Psoriasis vulgaris is typically localized in the extensors extremities, head, lumbosacral, buttocks, and genitalia. $^{1}$ 
Factors that provoke psoriasis in outpatients and inpatients the most are focal tooth infection, stress, and ENT infections. Several studies show that endogenous and exogenous factors could provoke psoriasis. Those factors include skin aggression, infection, alcohol and smoking, stress, drugs, hormonal changes, and allergy. ${ }^{1,15,17}$

All study subjects have no family history of psoriasis. It is contradictory to many other previous studies which reported that the percentage of psoriasis history in the family is relatively high amongst psoriasis patients; $17.5 \%$ in Egypt, $45.9 \%$ in Italy, $40.7 \%$ in Spain, $28.6 \%$ in the Maghreb, $23 \%$ in China, and $23.1 \%$ in Malaysia. ${ }^{18}$ The inheritance pattern of psoriasis is best described as multifactorial. The psoriasis concordance rate ranges from $35 \%$ to $73 \%$, which decreases nearer to the equator, suggesting the possible involvement of UV light as an environmental factor. ${ }^{1}$ The absence of family history in the study may be caused by an undetected case in the patient's family or other sociocultural factors deeming sickness a private matter or may be due to Indonesia being along the equatorial line.

Some of the subjects had unfitting histopathological results to psoriasis. It might be caused by the diagnosis firstly being made based on clinical examination. Still, the histopathology exam was done to assist the diagnosis of atypical and doubtful cases. ${ }^{19}$

Type $2 \mathrm{DM}$ and dyslipidemia were the most common comorbidity of psoriasis patients. Others were obesity, spondyloarthritis/arthropathy, hypertensive heart disease, and depression. Often, it is for psoriasis to be accompanied by comorbidities. Some classic examples are psoriatic arthritis, inflammatory bowel disease, psychiatric and psychological problems, as well as uveitis. Some of these may be caused by the genetic fragility of the psoriatic patients, while the condition itself greatly affects the quality of life and person confidence. This disease is related to anxiety and depression, with $30 \%$ and $60 \%$, respectively. ${ }^{20}$

Obesity, hypertriglyceridemia, and hyperglycemia also increase with psoriasis degree of severity, independent of other components of metabolic syndrome. ${ }^{20}$

In a cohort study for a systemic therapy for psoriasis patients that involves non-psoriatic patients, the hazard ratio is 1.53 (after adjustment to age, sex, diabetes, hypertension, dyslipidemia, and smoking). Chronic inflammation of psoriasis produces Th1 and Th17 that promote systemic inflammation. Proinflammatory cytokines stimulate the hypothalamus-hypophysis axis, which relates to central obesity, hypertension, and insulin resistance. In other words, psoriasis worsens obesity, diabetes, thrombosis, and atherosclerosis. ${ }^{20}$ Obesity is an independent risk factor for psoriasis as the risk increases with increasing BMI. Social isolation, poor dietary habits, depression, alcoholism, and sedentary lifestyle in psoriasis patients may explain why psoriasis can cause obesity. ${ }^{21}$ Further supporting evidence is shown by a cross-sectional study in the UK. Numerous epidemiological studies have concrete proof that obesity is a predisposing factor for psoriasis and worsens psoriasis inflammation. ${ }^{22}$ Some studies show positive effects of reducing body weight with reduced severity of psoriasis. ${ }^{21}$

At the time of admission, almost all psoriatic outpatients have severe psoriasis (PASI $>10$ ). By the time of therapy, $48.1 \%$ have moderate psoriasis (PASI 5-10), and $25.9 \%$ have mild psoriasis (PASI $<5$ ). PASI 75 success is achieved by $64.8 \%$ of outpatients. Although, the target of the therapy is based on several parameters, not only skin symptoms but also the quality of life. However, PASI 75 is currently used as a basis to measure primary outcomes of clinical studies for psoriasis. The goal remains at the complete recovery of skin lesions and $90 \%$ improvement or PASI 90, especially amongst severe psoriatic patients. Patients who do not improve at least 50\% in week 12 or 16 from the initial PASI score is called nonresponder. ${ }^{23}$

All psoriatic inpatients had a PASI score of more than 10 , indicating a severe condition. However, after the therapy, only a small portion whose severity decreased to moderate with PASI 5-10 (19.2\%). The percentage of subjects achieving PASI 75 is only $3.8 \%$. Inpatient subjects were more severe than outpatients at the beginning of their care, and the management of their condition was 'emerging'. Hence once they show improvement, they are discharged for home treatment. All inpatients subjects got systemic therapy of methotrexate or cyclosporin. PASI score evaluation in the systemic treatment of psoriasis needs to be done after at least 12 weeks, but their length of stay is shorter. It may explain why inpatient subjects do not achieve PASI 75. It was due to the limited time window. ${ }^{23}$

Three therapy modalities for psoriasis vulgaris are topical, systemic, and phototherapy. Topical medicine is for mild patients. For moderate to severe cases, a combination of topical and systemic are used. The majority of the outpatients received combination therapy (92.6\%). A small population gets a variety of the three modalities (7.4\%). All inpatients subjects received combination therapy. Methotrexate and cyclosporin were the most used topical therapy for 
both inpatients and outpatients. Cyclosporine was the alternative if treatment with methotrexate did not show clinical improvement. Methotrexate is a folic acid analogue that hinders the formation of nucleic acid in activated $\mathrm{T}$ cells and keratinocytes, hence becoming an antiproliferative agent and an immunomodulator in psoriasis. ${ }^{1}$ The drug is prescribed in divided doses to increase efficacy and minimize side effects. ${ }^{24}$

There are patterns in the profiles of psoriatic patients. Some are similar to other findings, such as the proportional relationship between obesity and psoriasis prevalence, as explained in an international study by de Oliviera, Kunz, and Takeshita. They reported that obesity is related to the inflammation process. The lack of family history in all subjects in this study contradicts other findings suggesting a strong familial relationship to the disease. Despite so, this may be due to a lack of testing or lack of awareness. The success of a treatment regimen depends on several factors such as degree of lesion severity, genetics, environment, pharmacokinetics, and pharmacodynamics.

\section{REFERENCES}

1. Gudjonsson J, Elder J. Psoriasis. In: Kang S, Amagai M, Bruckner A, Enk A, Margolis D, editors. Fitzpatrick Dermatology in General Medicine. 9th ed. New York: McGraw Hill Education 2019. p. 457-97.

2. Luo Y, Ru Y, Sun X, Zhou Y, Yang Y, Ma T. Characteristics of psoriasis vulgaris in China: a prospective cohort study protocol. Am Transl Med 2019;7(22):694.

3. Kerkhof P, Nestle F. Psoriasis. In: Bolognia J, Jorizzo J, Schagger J, editors. Dermatology 2. 3rd ed. Philadelphia: Elsevier 2012. p. 135-55.

4. Michalek I, Loring B, John S. A systematic review of worldwide epidemiology of psoriasis. J Eur Acad Dermatol Venereol 2017;31(5):20512.

5. Sinniah B, Saraswathy S, Prashant S. Epidemiology of psoriasis in Malaysia: a hospital-based study. Med J Malaysia 2010;65(1):112-4.

6. Zhang J. Epidemiology and risk factors of psoriasis. Pr J Clin Med 2013;1(2):4-6.

7. Gayatri L. Studi retrospektif: Psoriasis pustulosa generalisata. Berkala Ilmu Kesehatan Kulit dan Kelamin 2014;26(1):49-55.

8. Widaty S, Soebono H, Nilasari H, Listiawan M, Siswati A, Triwahyudi D, et al. Psoriasis. In: Iidaty S, Soebono H, Nilasari H, Listiawan M, Siswati A, Triwahyudi D, et al., editors. Panduan praktik klinis bagi dokter spesialis kulit dan kelamin di indonesia. 2nd ed. Jakarta: Perhimpunan Dokter Spesialis Kulit dan Kelamin Indonesia 2017. p. 230-40.

9. Dispenduk capil. Jumlah penduduk kota Surabaya [Internet] 2019. Available from:http://dispendukcapil.surabaya.go.id/berita/ 483-jumlah-penduduk-kota Sura

baya.

10. Novianto E, Irawan A, Wiryadi B, Prakoeswa C, Kariosentono H, Roesyani I, et al. Alur tata laksana psoriasis (tipe plak). In: Novianto E, Fitri E, Buadianti W, editors. Alur tata laksana psoriasis vulgaris (tipe plak) di Indonesia. 4th ed. Jakarta: Perhimpunan Dokter Spesialis Kulit dan Kelamin Indonesia 2019. p. 1-3.

11. Wong HR, Freishtat RJ, Monaco M, Odoms K, Shanley TP. Leukocyte subset-derived genomewide expression profiles in pediatric septic shock. Pediatr Crit Care Med 2010;11(3):34955.

12. Palfreeman AC, McNamee KE, McCann FE. New developments in the management of psoriasis and psoriatic arthritis: A focus on apremilast. Drug Des Dev Ther 2013;7(2):20110.

13. Haag D, Sundstrom A, Eriksson M, Egenolf M. Severity of psoriasis differs between men and women : a study of the clinical outcome measure psoriasis area and severity index (Pasi) In 5438 Swedish Register Patients. Am J Clin Dermatol 2017;1(1):1-5.

14. Jacoeb T. Psoriasis. In: Menaldi S, Bramono K, Indriatmi $\mathrm{W}$, editors. Ilmu penyakit kulit dan kelamin. Jakarta: Badan Penerbit Fakultas Kedokteran Universitas Indonesia 2015. p. 21321.

15. World Health Organization. Global report on psoriasis 2016; 1(1): 1-10

16. Setyorini, M Triestianawati W, Wiryadi B, Jacoeb T. Proporsi sindrom metabolik pada pasien psoriasis vulgaris berdasarkan kriteria national cholesterol education program adult treatment panel III di RS Dr. Cipto Mangunkusumo dan sebuah klinik swasta di jakarta. MDVI 2012;39(1):2-9.

17. Xhaja A, Shkodrani E, Frangaj S, Kuneshka L, Vasili E. An epidemiological study on trigger factors and quality of life in psoriatic patients. Mater Socio Medica 2014;26(3):168-71.

18. El-Komy M, Mashaly H, Sayed K, Hafez V, ElMesidy M, Said E et al. Clinical and epidemiologic features of psoriasis patients in an egyptian medical centre. JAAD Int 
2020;1(2):81-90.

19. Ferreli C, Pinna A, Pilloni L, Tomasini C, Rongioletti F. Histopathological aspects of psoriasis and its uncommon variants. Genital Di Dermatologia e Venereol 2018;153(2):173-84.

20. Rocha B de O, Duarte G. Psoriasis: classical and emerging comorbidities. A Bras Dermatol 2015;90(1):9-20.

21. Kunz M, Simon J, Saalback A. Psoriasis: obesity and fatty acids. Front Immunol 2019;10(5):180 7.
22. Takeshita J, Grewal S, Langan S, Mehta N, Ogdie A, Voorhes A. Psoriasis and comorbid diseases epidemiology. J Am Acad Dermatology 2016; 12(1): 377-91.

23. Gisondi $\mathrm{P}$, Del Giglio $\mathrm{M}$, Girolomoni $\mathrm{G}$. Treatment approaches moderate to severe psoriasis. Int J Mol Sci 2017;18(11):2427.

24. Panduan Pelayanan Klinis (PPK). Psoriasis vulgaris. SMF kesehatan kulit dan kelamin RSUD Dr. Soetomo Surabaya 2016;1(1): 1-5 